\section{Divide In Marketing Between Academics And Practitioners}

\author{
Fernanda Capanema Repsold ${ }^{\dagger}$ \\ Pontifícia Universidade Católica do Rio de Janeiro PUC-Rio \\ Marcus Wilcox Hemais $\Omega$ \\ Pontifícia Universidade Católica do Rio de Janeiro PUC-Rio
}

\section{ABSTRACT}

In marketing, there is a clear divide between academics and practitioners. However, there are few empirical studies in Brazil that help clarify the phenomenon. In light of this context, the present research seeks to understand how academics and practitioners perceive the divide between the academy and businesses and how this affects the applicability of theories, concepts and models in marketing. For this purpose, in-depth interviews were conducted with ten academics who teach marketing and 15 practitioners involved in the area. The reasons for the divide are presented, with emphasis on how the teaching of marketing contributes to the phenomenon. The paper shows how the divide affects the applicability of the discipline, and it gives suggestions on how to reduce the divide. Academics and practitioners show interest in reducing the divide. The difficulties for this to are owing to the different understandings of what marketing is. Such an inconsistency can be explained based on the purposes/reasons that lead these professionals to practice the discipline.

Keywords: Marketing theory; Marketing practice; Academic context; Practitioner context.

\section{INTRODUCTION}

When leaving college, it is common for marketing students to encounter a different reality than expected. After years of learning in a system that values theories, concepts and models, they reach a market reality that is based on experience and intuition. This helps to understand why few marketing practitioners feel that they are making full use of their knowledge in everyday tasks (DELOITTE, 2015).

In the area of marketing, it is acknowledged (HUNT, 2002; LILIEN, 2011; STANTON, 2006) that there is a divide between academic and business environment. The reason for this divide, however, is not clear. There are different explanations for this phenomenon, which attribute "guilt" to the academy and, also, to companies and practitioners for lack of proximity between them (LEE; GREENLEY, 2010; PACHECO; RODRIGUES; SOUZA, 2013).

In spite of the divide, marketing continues to be an academic discipline that is valued and sought out in the business environment, but not through a direct relationship with universities. When in need of performance improvements, companies use consultancies to receive
Corresponding author:

† Pontifícia Universidade Católica do Rio de Janeiro PUC-Rio

E-mail: fernandarepsold@gmail.com

$\Omega$ Pontifícia Universidade Católica do

Rio de Janeiro PUC-Rio

E-mail: mhemais@gmail.com

Received: 06/06/2016.

Revised: 08/23/2016.

Accepted: 11/16/2016.

Published Online: 11/01/2017.

DOI:http://dx.doi.org/10.15728/bbr.2018.15.1.5 
mediation involving the exchange of knowledge and skills development. Ironically, several of these consultants are university professors (EMPSON, 2013).

This context leads authors to discuss how much the academic and business circles should be brought together. Some believe in the benefits of closer proximity between the parties and suggest ways to minimize the divide (KLAUS; EDVARDSSON, 2014; LILIEN, 2011). Others, however, believe that attempts to strengthen their relationships are fruitless, because they have distinct objectives and, therefore, the divide should be a secondary concern for academics (BRENNAN, 2004; BRENNAN; ANKERS, 2004). Given that the marketing discipline should not be viewed as being created "by academics for practitioners", but rather serve the purposes of "diverse stakeholders", the attempt at proximity would in fact only bring frustrations to those involved (HUNT, 2002).

In areas such as medicine and law, practitioners turn directly to academic research as an important source of information (LEE; GREENLEY, 2010). They perceive such studies as true references, neutral to interference from large corporations interested in biasing results to further their goals, and use such findings to base their thoughts. Why, then, do we lack the same reality in marketing?

Researchers in Management have been dedicated to understanding the divide between the academic and business environments (FARIA, 2007; HUGHES et al., 2011), including within the marketing area (KAUPPINEN-RÄISÄNEN; GRÖNROSS, 2015). However, although the discussion is widespread in the marketing literature from the United States and Europe, research on the subject in Brazil is scarce (ALMEIDA et al., 2010).

Authors in Brazil have been debating this issue, taking into account the need for greater rigor and relevance in marketing research so that the divide does not widen, but preferably diminishes (SAMPAIO et al., 2012). However, they do not consider historical aspects that make this approximation difficult (FARIA, 2007) and present few empirical studies that help to understand the phenomenon more clearly. Little is known, therefore, how those who study or practice marketing in Brazil position themselves regarding the phenomenon. Given this context, the present study seeks to shed light on this gap in the literature by understanding how academics and practitioners perceive the divide between academic and business environments and how this affects the applicability of the main theories, concepts and models in marketing. This larger objective is divided into three specific objectives in order to better understand (1) the reasons for the divide between the two environments, (2) the role of marketing teaching in this divide and (3) the reasons for the difficulty in the applicability of marketing by companies following how it is taught in the academy.

The rest of the study is divided into four more sections. The second presents the literature that discusses the distance between the academic and business environments. Then, in the third, the methodological choices are debated. The fourth section analyzes the data collected through interviews conducted with academics and practitioners. Finally, the fifth section offers the final considerations of the study.

\section{THE DIVIDE BETWEEN ACADEMIA AND BUSINESS}

One of the main characteristics of theories is that they create structure and regularity, resulting in a system that can be corrected and improved over time. Theories are like 'networks', which are intended to 'recognize' what we call the world. Only in this way can we $u$ and rationalize, in order to understand the world. Based on this, we understand that theories are tools to map reality and transform information into knowledge (HEGENBERG, 1976). Theories must first explain the occurrence of phenomena, in addition to systematizing and organizing knowledge about such phenomena. Furthermore, they must deduce what will happen and guide the method of happening of a phenomenon (BRUYNE, 1991). 
BBR

15,1

70

In spite of such objectives, Kerlinger (1980) explains that frequently theories are alienated from everyday life, because they are difficult to prove and, therefore, have little practical relevance. Thus, most people make decisions on a daily basis using personal estimates of possible consequences. These estimates are guided by "personal theories", which may be poorly developed and grounded on limited information.

Theories in marketing differ from personal theories because they are based on a systematic combination of research and logic. They are ideas presented in books and articles, to be evaluated and reviewed by scholars. Marketing theories also differ from theories of exact sciences because, for marketing, the description and the analysis of the factors that make up the phenomenon are more important than clarifying and explaining such phenomenon (ASTLEY; ZAMMUTO, 1992). Marketing theories, therefore, observe reality in a systemic way, addressing and explaining all of its known and observed characteristics, rather than providing a detailed description of some specific phenomenon (HUNT, 2003).

Since the beginning of the 20th century, marketing theories have undergone changes (BARTELS, 1976), which, as a consequence, have also affected marketing theorizations (SHETH et al., 1988). Although these changes have emerged from developments within the academy and business, it is common for the usefulness of marketing theories in the market to be questioned, and this leads to the distancing between the academic and business circles (BAKER, 2000).

Various scholars (BROWNE; CUDDIHY, 2011) believe that the impact of academic work for practitioners is limited, thus minimizing the importance of knowing theories, concepts and models in marketing for the effective performance of companies. Criticisms towards academia range from the lack of applicability of what is being taught in universities to the apparent incapacity of scholars to make their research sought after and cited as a reference by the market (BAKER; HOLT, 2004).

Unwieldy language, complex modeling and lack of understanding of the "real world" are the main reasons practitioners consider academic studies irrelevant. The academic literature ends up losing its attractiveness to practitioners because it does not use language accessible to the market (EDWARDS, 2005). This helps explain the reason why Kauppinen-Räisänen and Grönroos (2015) indicate that there is little knowledge in companies about the latest academic research and theories, since the willingness to incorporate such knowledge into practice is almost nil. As a consequence, what happens is the partial or incorrect application of concepts (such as internal marketing and quality of services) advocated by the authors as important for companies to have competitive differentials.

One can add to this discussion the fact that theories are considered generalist, with multiple possibilities of application. Therefore, their predictive power and capacity to be applied in a singular business context are weakened, since, in its conception, the theory had not been created to be particularized (HE; MUKHERJEE, 2007). This ultimately causes marketing research published in academic journals to be ignored by marketing practitioners. The business world realizes that such theories are often formulated in a generalizing way, which makes them unrelated to markets and, therefore, difficult to adapt to practical problems (KAUPPINEN-RÄISÄNEN; GRÖNROSS, 2015).

It is curious, however, that for practitioners interviewed by Almeida et al (2010, p.12), "the books published by Kotler seem to be the marketing guide in the search for solutions and approaches to day-to-day problems and planning". Possibly, the marketing guru's books are the only academic references with which practitioners have contact, since they are widely adopted in business schools world-wide (BOURASSA et al., 2007). Thus, it is natural for practitioners to believe in the generalization of theories in marketing, since their awareness of them is limited to one author and his textbooks, which are essentially generalist. It is not surprising, therefore, that marketing practitioners barely use theories, 
concepts and models in marketing, since, as pointed out by Lilien (2011), only a small number know much about them.

Research interests between academics and practitioners also differ in their objectives. One of the differences is based on the premise that academics tend to seek a detailed description and to analyze in depth the characteristics of a phenomenon, to better illustrate the relations between concepts. Practitioners, in turn, focus on a specific problem, with the purpose of developing strategies and actions to solve it (ALMEIDA et al., 2010). Indeed, by focusing on one aspect of the phenomenon, academics are accused of intentionally generalizing, which is a form of gaining theoretical significance. Practitioners, differently, are concerned about short-term actions, which concern the immediate and specific problems with which they are confronted (BAINES et al., 2009).

To describe this business behavior, Argyris and Schon (1974) created the concept of "theory in activity". The authors explain that the assumptions about the person, the others and the environment in which one is inserted constitute a microcosm of the science of everyday life. Experiences and skills developed over time by practitioners, therefore, give them knowledge about the problems faced in the daily life of the organization in which they work. This knowledge functions as a "functional theory" and all information collected in research by these practitioners is processed only as additional information. These "functional theories" are usually assumptions and intuitions that guide strategies, to solve specific marketing problems that these practitioners experience. When these assumptions and strategies based on "functional theories" work, they become the norm in the environment where they were applied.

Faced with the divide between academic and business circles, it is common for companies not to appeal to scholars when they need help; instead, they hire consultants. However, the business environment could possibly save on consultancy costs if it had better knowledge of theories, concepts, and models in marketing (EDWARDS, 2005). On the other hand, there are those who believe that academics know little what marketing managers do and what companies need, which makes them disqualified to provide concrete and relevant advice (BRENNAN; ANKERS, 2004). Consultants, in this case, would adapt better to the task, since they would involve themselves in the reality of the company, understanding more fully the complexity of the problem and providing objective solutions and a course of immediate action (BAINES et al., 2009).

The divide between these environments, however, is not seen in a negative way by all. Different authors (BRENNAN, 2004; BRENNAN; ANKERS, 2004) believe that practical and theoretical orientations in marketing are intrinsically distinct and, therefore, should remain separate, so that there is no intervention and mediation of practitioners in academic work. These authors also question whether practitioners should really be the true beneficiaries of academic research in the area. For them, a piece of academic work in marketing that provides a benefit to society brings a contribution as valid as one that can be applied in markets, which justifies in itself the search for this type of knowledge.

Other authors (KLAUS; EDVARDSSON, 2014; LILIEN, 2011), however, disagree with this line of thinking, because they believe that, although there are general differences in practical and theoretical orientations, both should be complementary, rather than competitive or exclusive. Roberts et al. (2014) also show that managers of large companies use scientific marketing knowledge to base their decisions, more specifically the kind related to branding, pricing and development of new products. Along these lines, Rowley (2012, p.522) believes that such an approach between academics and practitioners is occurring because there is an "increasing awareness of the importance of knowledge, skills and creativity for the performance of companies".

In order to bring both parties together, a greater sensitivity on the part of academics is necessary regarding the nature of the thought and behavior of those who are studied 
BBR

15,1

72

and their companies, in order to develop knowledge that is useful to the business reality. Stanton (2006) proposes that this be achieved through greater practical emphasis on the teaching of marketing. The author advocates his argument when reporting the success of a data mining discipline he administers, which has been "very well" evaluated among his students because it prepares them better for the business environment, where companies give great value to professionals with such knowledge.

The lack of consensus on whether there should be efforts to reduce the divide between academic and business circles shows the need for further discussion in this regard, especially if those who experience the effects of this phenomenon - that is, academics and practitioners - are given a chance to voice their thoughts.

\section{METHODOLOGY}

In order to reach the final objective of the present study, the authors conducted a qualitative, exploratory research. Due to the scarce knowledge about the topic in the Brazilian reality (ALMEIDA et al., 2010), we understand that exploratory research is the most adequate choice, since it allows the researcher to become familiar with the phenomenon in question. The option to adopt a qualitative research was due to the greater freedom that this type of research offers interviewees to express their opinions (DUARTE, 2004).

Because this study aims to understand two perspectives on the divide between academic and business environments, the authors interviewed 10 academics who teach marketing and 15 practitioners involved in marketing activities. The selection of the participants of the research was by convenience, since the researchers had contact with professionals from both environments.

One concern the authors had was to interview professionals with diverse profiles, in order to present a broad view of the phenomenon. Thus, the academics were from private and public universities in Rio de Janeiro, with classroom experience that ranged from one year to 35 years, some being part-time lecturers, while others where full-time professors. the part-time lecturers indicated that their other main professional activity was consulting, coherent with the logic that they are valued for their ability to apply academic knowledge in business environments (EMPSON, 2013). All respondents had teaching experience in both undergraduate and postgraduate levels.

The practitioners were from different sectors (telecommunications, consumer goods, banking, cosmetics, among others), company sizes, market experience (between two and 30 years), positions (analysts, coordinators, managers, directors and presidents) and ages (between 24 and 55 years). Among those interviewed, there were some who had completed their higher education in courses such as Business Management, Advertising, Journalism and Language Studies. Two respondents who had no training in Business Management reported missing such academic knowledge in their professions. One respondent - who graduated in Journalism and, today, is a Marketing Coordinator - reported that after four years in the market, she took a postgraduate degree in marketing because she lacked "specific knowledge", which gave her "a disadvantage" in relation to the people with whom she worked.

Few practitioners teach or have taught courses at universities. Of the respondents who answered that they did not have such experience, some showed an interest in teaching or participating in the academic environment in one way or another. However, "lack of time" seems to be a major impediment to engaging in this activity. 
The interviews were guided by a script, based on the theoretical framework. In particular, the studies by Almeida et al. (2010) and Kauppinen-Räisänen and Grönroos (2015), whose research objectives were in line with that of the present study, were important for the development of the interview script, since the authors discussed how they developed their own scripts, and this served as support in the elaboration of the questions used here. The script contained questions grouped into four main themes, with the intent of collecting data about (1) the profile of the respondents, (2) the importance of theories, concepts and models in marketing for business practices, (3) the importance of marketing education for business pratices, and, finally, (4) the relationship between academic and business environments.

The interview script was pre-tested with three teachers and two practitioners, to ensure easy understanding of its content. Since the interviewees did not show difficulties in understanding what was asked of them and their answers provided information that was relevant to the objective of the study, the authors understood that the instrument was valid for the process of data collection.

The interviews were carried out in the universities where the academics teach and in the companies where the practitioners work. Care was taken to conduct them in private places, with the aim of the respondent having enough privacy to present their opinions. Each interview lasted, on average, 45 minutes, and the total recording was 1,127 minutes of conversations, which were later transcribed. There was no concern to establish an ordering of the respondents, which meant that academics and practitioners were interviewed according to the dates when it was possible to schedule the interviews.

The data analysis was done in two stages. Initially, transcripts of the interviews were coded using the Atlas.ti program, in order to organize the collected reports. In all, 118 codes were created, based on the literature presented in the theoretical reference and on specific facts that emerged in the respondent's reports (RUBIN; RUBIN, 2005). This step allowed the authors to determine when the saturation of the data was reached, from the moment in which new codes no longer appeared during the codification of the transcriptions (GUEST; BUNCE; JOHNSON, 2006).

The saturation of the data was determinant to establish the number of professionals interviewed. As each interview was coded, the number of new codes diminished. Around the 22nd interview that was coded, there was no new information that demanded new codes to be created. This followed until the 25 th interview, which led the authors to establish that it was not necessary to interview any more professionals.

In the second stage of analysis, the authors compared each respondent's report with those of others and with the theoretical framework, with the aim of finding similarities and differences in the interviewees' view of the studied phenomenon (GUMMESON, 2005). After these steps, it was possible to define the categories of analysis of the study, presented below. Table 1 illustrates how the categories of analysis were developed based on the codes that were created during the interview coding process. 
BBR

15,1

74

Table 1. Categories of Analysis and associated codes

\begin{tabular}{|c|c|c|}
\hline Categories of Analysis & Code examples in each category of analysis & $\begin{array}{l}\text { Total codes per cate- } \\
\text { gory of analysis }\end{array}$ \\
\hline $\begin{array}{l}\text { Reasons for the divide in } \\
\text { marketing between academia and } \\
\text { business. }\end{array}$ & $\begin{array}{l}\text { The academy as responsible for the divide; } \\
\text { lack of detail on market issues in marketing; } \\
\text { marketing as an unfeasible orientation in } \\
\text { companies; adapted marketing in companies; } \\
\text { difficulties with academic language; different } \\
\text { rhythms between academics and practitioners; } \\
\text { consulting; different realities; Capes pu- } \\
\text { blishing goals... }\end{array}$ & 36 \\
\hline
\end{tabular}

Purposes of marketing teaching; teaching undergraduate marketing; teaching marketing in graduate school; characteristics of undergra-

Marketing education as a means duate students; characteristics of postgraduate to approximate or divide.

students; Marketing deficiency in undergraduate school; practical experience; more practical classes; lectures; little access by practitioners to academic marketing knowledge...

Marketing as a holistic activity for academics; marketing as specific actions in companies; marketing as a chain of complementary events; lack of knowledge of practitioners

Difficulties applying marketing to companies.

about marketing concepts; structure of marketing in companies; marketing as sales or communication; practitioner adapts to the company; lack of time for practitioners; marketing and business strategy...

Practical suggestion; approach to improve marketing image; greater business experience in classes; continuous actions; approximation through institutional actions; example of apin marketing between academic and business environments.

proach action; student transition; actions to value marketing teaching...

\section{PRESENTATION AND DATA ANALYSIS}

The present section is organized into four sub-items. In the first one, the reasons given by the respondents for the divide in marketing between the academic and business environments are discussed. In the second, the ways in which the teaching of marketing relates to the divide are discussed. In the third, the applicability of how marketing is affected by the divide is analyzed. Finally, suggestions on how to reduce the divide are offered.

\subsection{REASONS FOR THE DIVIDE IN MARKETING IN ACADEMIC AND BUSINESS CIRCLES}

The idea that there is a divide in marketing between academic and business circles was evident in the respondents' reports. Some practitioners even accused the academy of being responsible for producing this gap and thought that it would be up to the academy to diminish it. According to one of the respondents (Director, food industry, 25 years of experience): "The market survives without academia. It is there, fulfilling its role, working well. It is the academy that needs to seek this approach". 
This view of practitioners putting the blame on the academy for the divide between academic and business circles shows that they have a limited perspective on marketing. According to Hunt (2002), the discipline was not created for the sole purpose of reflecting on business practices or creating tools for the use of companies. Marketing, in fact, is responsible for several stakeholders, among them society, students, academics and businesses. Thus, the author argues that those who look to marketing only for the fulfillment of their own purposes demonstrate that they do not have a coherent and well-founded conceptualization about the nature of the discipline.

Academics and practitioners list several reasons that would lead to the existence of this divide. There is an understanding that marketing teaching is important so that students are aware of what the discipline offers. However, in practical reality, a significantly greater depth is needed, due to "various details" related to markets, and this depth is not offered in universities. And, in principle, these "details" would be the most important elements that a practitioner could have to properly exercise marketing, according to one interviewee (Coordinator, telecommunications industry, 8 years of experience):

The small challenges of everyday life are hard for the academy to realize, and I do not think they would even be of interest. The company may have specific challenges, political issues and internal relationships, for example, that are difficult to predict. The academy ends up having a more general panorama and does not address the daily life of companies.

The specificities of particular sectors, especially those with restrictive legislation, such as cigarettes, would be an example of how these details are important. One of the respondents explained that companies in this sector face great difficulties in seeing in marketing a viable orientation, because they cannot communicate their products in traditional media or sell them to any type of retailer. They end up resorting to "specific marketing practices" as alternatives or else creating their own "marketing", that is to say, a form of marketing applied specifically to their reality. One practitioner, who works as an analyst at a beverage multinational, explained that the company has a marketing education center called "Marketing Academy", where the theoretical knowledge specific to this market is valued. Employees also participate in an "internal university", in which they receive classes and take tests.

Part of what leads practitioners to think this way may be that they cannot "penetrate a world that seems to be only of the academy". The "unwieldy" and "generalist" language, the form of hermetic writing, the "very long" texts and the creation of complex models make academic works commonly no longer attractive to practitioners (EDWARDS, 2005). "Why use so many parentheses, with names of people and years at the end of sentences in academic texts?", questions a practitioner. The academy seems to have its own rules about how to communicate its findings, which makes its discourse difficult to grasp for those outside this context (HUGHES et al., 2011).

There is also a perception among the interviewees that academics and practitioners work in "different rhythms", and, for the second group, there is a "greater sense of urgency" because they need to be up-to-date so as not to losetheir competitive advantage. Southgate (2006) explains that creating a sense of urgency in the business environment is common and important, as it serves as a driving force for the ongoing quest to increase sales and profits in organizations and a justification for all business actions to have consequences (positive, preferably) in the short term. Scholars, on the other hand, need more time to reflect on certain phenomena and, thus, generate a relevant analysis. However, for practitioners, this period of reflection has a negative meaning, because they believe that it is an idle time, therefore, poorly spent. They understand the importance of this reflection for academics, 
BBR

15,1

but believe that in their realities they do not have time to do the same, as one practitioner indicates (Analyst, cosmetics industry, 2 years of experience):

The wave of demand makes it difficult to stop to reflect. It is almost a paradigm shift to try to apply concepts, instead of letting everything roll... It's very difficult to try to stop to think when you know you have a lot of things going on in the work dynamics.

According to one respondent, "When we want to think, we hire a consultant". The consultancy supplies the need to "think" of practitioners, because it is seen as an analytical institution capable of proposing solutions to problems of practitioners. One can do this because its main activity is to evaluate a situation and reflect on how to deal with it. It is no wonder, therefore, that academics are consultants, since their original profession requires such form of thought (EMPSON, 2013). Almeida et al. (2010, p.16) discuss the idea that, in the role of consultants, academics are able to influence practitioners and propose paths linked to academic studies, provided they are not "unworkable and unrealistic ideas for the reality of the company in which they are doing the work". This greater ease of influence on companies occurs, in some cases, because consultants are "placed on a pedestal", owing to the fact that they have a wider range of knowledge than practitioners and know how to apply it correctly in specific business contexts (HUGHES et al., 2011).

The reflective role of academics seems to be useful for practitioners when they are in difficulties. When asked about this issue, practitioners responded that the attitude of academics when engaged as consultants changes, since they adapt to the business reality, as they can be "less theoretical and more objective". The academic side of the consultant, then, is "set aside" so they can be, as one respondent indicates, "more professional", as if "professional" represented a posture of more attention or seriousness, considering the negative consequences that a mistake of analysis could entail. An academic, on the other hand, would have more freedom to make mistakes, because they are inserted in an environment that allows such misconceptions, so that they can be more relaxed regarding the results of their analysis. The following report shows how this dynamic occurs. A practitioner, who is a manager of a banking company and has 23 years of experience, explained how a colleague, who also acts as an academic, needed to change the way he presents his arguments to his superiors:

He performed a real academic work when he arrived here, using graphs, theoretical basis for all decisions... But, when he used to take this approach to meetings, our superior used to say: 'Tell me where you are getting at, speak fast, within one line'. Over time, he changed the way he worked, because he realized that he needed to adapt. But, the knowledge he has makes his works perfect, complete, even after he started to act in the same way as practitioners.

What adds to the thought that there are different rhythms between the academic and business environments is the speed with which new technologies emerge, especially those related to digital media, and the "urgency" with which academics and practitioners incorporate them into their professions. In the opinion of the respondents, while the market is concerned with this, "the academic environment takes time to be aware of all this news". What is studied and taught by academics in relation to digital media, for example, ends up being considered outdated by practitioners, even if they are technologies that were launched two or three years ago; for the market, technological innovations are those that have been launched "at the latest, in the last year".

It seems that for practitioners it is more difficult for their realities to coexist than it is for academics. There is the impression that they are under greater pressure, they carry out 
more activities in their day to day and practitioners have more to lose than academics. In a way, they demonstrate to know little about what academics do, imagining that, for the most part, they only give classes and nothing else. They reinforce the "joke" that asks the question if whether an academic "only teaches or works?" They thus show that in the same way that they blame academics for holding responsibility for the divide in marketing, they themselves do little to change the phenomenon.

Another factor, raised by academics, that contributes to the distancing of marketing is the "interference by CAPES (Coordination of Improvement of Higher Level Personnel)". The imposition of publication targets for academics meant that, in the opinion of the respondents, the number of published articles increased, but their quality decreased: "It is difficult to imagine that a professional will have an interest in reading these articles and can find valuable articles within this new scenario. Mass publication diminishes even the interest of teachers themselves", as one academic clarifies (a professor at a public university with 14 years of experience). Perhaps, therefore, academics lack the ability to make their research sough after and cited as referrals by practitioners (PFEFFER; FONG, 2002).

One issue that the interviewees discussed in relation to the divide between academic and business circles is the way in which marketing is taught. Since the interviewees brought up several reasons for this, the issue gained greater emphasis, and so it will be discussed further in the next section

\section{2. MARKETING EDUCATION AS AN APPROXIMATOR OR DIVIDER}

Academics and practitioners understand that marketing education has different purposes, depending on the level at which the course is taught, either at undergraduate or postgraduate level, and that the purposes affect the divide between the academic and practitioner environments. Undergraduate students, for the most part, have little practical experience and, therefore, marketing would serve to introduce them to a business reality, "open their eyes" to the way in which a company needs to develop itself in the market in which it is inserted, as one academician reports (professor of a private university, with 35 years of experience):

I believe that teaching marketing is for you to know the strategic role of marketing in the organization, from customer analysis to marketing application in practice. It is very much a matter of making the student understand marketing as a connecting link [sic] of all other areas of business for a common goal.

These students are seen as not having enough maturity to understand what markets are, which affects their ability to incorporate the core marketing elements. On the other hand, graduate students "can better understand what happens in the market", since, in general, they have been employed for a longer time. Thus, they expect marketing classes to offer them tools that enable them to improve their professional performance.

Because the education in marketing at the undergraduate level has a more introductory perspective, some respondents believe that undergraduate learning is "very shallow". This thought runs counter to findings that show how certain undergraduate marketing disciplines may have, in fact, great corporate relevance, as Stanton (2006) indicates when he talks about his data mining classes, which students readily accepted because of the results that their knowledge brought them to obtain better performances in companies. To circumvent this "disability" and become "more fluent" in marketing in order to use its theories, concepts and models more easily, it becomes necessary to have a postgraduate course, preferably a Masters. However, even at this level, a practitioner (Manager, event industry, 13 years of 
BBR

15,1

78

experience) questions if whether such education offers a "package that prepares someone for the market", arguing that:

Studying marketing and working with marketing are very different things. I remember that when I was in college, marketing seemed to always have glamor. But, in practice, it involves a lot of 'hard work', staying up many nights. The person always has to be switched on, not everybody is made for it. In the academia, one cannot have this understanding.

This line of thought leads graduate students, therefore, to better value the expansion of their professional network and the exchange of experiences with other practitioners from different markets more than the knowledge presented to them. Deep down, some practitioners admit, "what matters is the diploma", because it represents promotions of positions and an increase of remuneration.

In order to become a "full" marketer, in the view of the respondents, it is essential to have practical experience. Perhaps, because of this, academics are concerned to incorporate lessons about markets into their classes. They then use a variety of devices that are believed to provide students with lessons about the reality of companies, empowering them to comment on and understand how the business decision-making process occurs. Among these devices are the use of teaching cases, case studies and lectures by practitioners. Participants invited to lecture at universities are generally acquainted with academics. There is a belief that practitioners would only be interested in such activity as a personal retribution and that, otherwise, no one would be willing to lecture, since "they do not have the slightest interest, they even disdain the academy". On the other hand, the practitioners interviewed showed a desire to share their experiences with university audiences. In certain conditions, they even see it as prestigious to receive such an invitation. However, few have done it, claiming that they "never" are contacted, although they receive such requests from "several" nonacademic institutions, as one practitioner reports (Director, arts and entertainment industry, 30 years of experience):

Associations and companies are looking for me to give lectures much more than the academy, unfortunately. I get several emails and invitations from strangers to attend seminars in my area. With the academy, this hardly ever happens.

Academics are careful to present students with updated content, which is also intended to keep teachers in line with market trends. It should be pointed out that this concern to use updated material is not only focused on the practical examples used in the classroom; there is also awareness that not all theories, concepts and models in marketing are still relevant. While some are considered "universal", applicable in any context, others are "very private" or "out of date", calling into question how appropriate the textbooks used in the classroom are for the Brazilian academic and practical reality.

Some academics who are also consultants emphasize the importance of this professional experience for their teaching career. They claim that it helps them to present cases more effectively when they experience them in companies, as experience makes it easier to relate cases to theories, concepts, and models in marketing. "The market forced me to learn about internet marketing, for example. As a teacher, I would not have such an emerging need. But to work with an online customer, I need to have a basic understanding of the market", as one academic reports (professor at a private university, with 4 years of experience). The benefits of this "double life" (EMPSON, 2013) are not just for teaching, because they believe that their theoretical knowledge also helps them to be better consultants, since they have a "macro vision" for solving business problems. 
If academics have an intention to "incorporate market practices in academia", the same does not seem to occur when it comes to practitioners approaching the academy to improve their performance. Although there is a discourse that academic marketing education is important, the content produced by academics is hardly ever accessed by practitioners. Few respondents were interested in keeping up-to-date on theories, concepts and models in marketing, whether by reading academic articles or attending conferences (as foreseen by Mascarenhas et al., 2011), even among those who teach or have already taught. The only sources of information mentioned were Harvard Business Review, HSM Educação Executiva magazine, IESE magazine and LinkedIn (which, despite being a site of professional relationships, provides academic articles), all with a professional bias. Academic journals, properly speaking, were not even mentioned, even the most famous ones, such as the Journal of Marketing. Apparently, the reason for not reading such journals is the lack of knowledge of "where to find them". But, even if they did "find" the journals, the lack of time also makes them leave such readings aside (SOUTHGATE, 2006).

There is a concern among practitioners to keep informed about what is happening in the market, especially about knowledge that is related to their professional activities. For this purpose, they consult books, newspapers, magazines and the internet. Several examples of books cited by them were written by scholars, and they became bestsellers because they present a more practical view of some theory, concept or model. According to one interviewee (Manager, retail sector, 5 years of experience), "The results of the research explained in these books always bring good insights to our business". Curiously, none of the books cited were written by Brazilian scholars.

Southgate (2006) explains that, although practitioners do not always read bestsellers, they purchase them more as a source of inspiration, innovation and stimulation rather than knowledge, and also because this kind of book is comprehensive and innovative literature. Therefore, even if they are marketers, they do not read marketing books, as there are few that become international literary successes. This also explains why they do not read academic articles, as they end up being "too specific and not specific enough" (p.550). In addition, academic articles bring a "burden" to practitioners which they have to explain to their peers the importance of adopting the concepts, theories or models discussed in articles for business practice, since they are not part of a list of knowledge commonly accepted in this environment. What is important, then, is not for practitioners to read academic articles, but rather to have access to the knowledge generated by them, whether in the form of textbooks, consultancies, lectures, journals, marketing journals or other sources that they access more often than traditional academic writing (HUNT, 2002).

Almeida et al. (2010) show that in addition to the literature, marketing practitioners also seek to keep up to date through participation in events, lectures and seminars, many of which are paid for by their companies. The problem, however, is that few of these focus on marketing; instead, their context in general more related to management, negotiation or specific themes of the area of activity of the company. When they want to specialize in marketing, practitioners need to pay for their own courses, which makes the search for qualification and access to academic knowledge more difficult.

Another way in which practitioners can acquire current and relevant academic knowledge, as argued by Hughes et al. (2011), is the hiring of new graduate students from universities, both at undergraduate and postgraduate level. The authors show that their respondents believe that such a practice is valid, since it renews the type of knowledge in the company and brings another vision, less dependent and outdated, different from the one most senior practitioners of companies provide. Such a practice, however, was not reported by the respondents of this research.

The reasons that lead the respondents to perceive a marketing divide between the academic and the business environment have consequences for the applicability of marketing. The 
BBR

15,1

80

next item discusses this issue, pointing out how marketing in practice seems to differ from how academics and practitioners advocate its implementation.

\subsection{THE DIFFICULT APPLICABILITY OF MARKETING}

The reasons that lead respondents to perceive a divide in marketing between the academic and business environments bring consequences for the applicability of marketing. Scholars and practitioners differ as to what is important for marketing to be practiced correctly. While the former understand that marketing is a holistic activity, which only "works" if all its elements are implemented together, the latter point to a different view, indicating only one concept or another as necessary. From this perspective, theoretical orientations and practices in marketing seem intrinsically dissimilar. While, for practitioners, thinking based on known theories means applying them, for academics, the rigor of this application carries considerable weight. According to Mascarenhas et al. (2011), practitioners adapt marketing to the reality of their companies, even if it means not following the academic way marketing should be implemented. In some cases, "one can even practice marketing without believing in it" (ALMEIDA et al., 2010, p.11). A practitioner (manager, publishing sector, 12 years of experience) exemplifies this thought in the following account:

I use the theories for myself. I cannot stop to write a paper about them. Occasionally, I write down some theories on paper, to think about them better, but it is something specific. In general, this exercise is done in my head, using the rationale I learned in college. This is my way of applying it. It's hard for one to see applied theory as in college cases, with everything all right.

The different views of the respondents can be explained by the fact that academics teach marketing (and in some cases, they practice it) as a chain of complementary elements, without which the discipline "does not function". On the other hand, practitioners commonly exercise only one of these elements in their activities, so they have difficulty seeing marketing as more than just that, a finding also reached by Baker and Holt (2004), when they show that their respondents equate marketing with promotions or communication campaigns.

In some cases, practitioners claim that they are unaware of certain theories, concepts and models which, supposedly, "are well known", according to one academic, and they do not remember having studied them in their university courses. In other cases, practitioners confuse what a certain concept means and minimize its importance. One of the respondents (Coordinator, food industry, 15 years of experience), for example, stated that he knew "Environmental Analysis", but said that this analysis "is not widely used because, unfortunately, we have not yet incorporated sustainability as one of our values". This result was also found by Kauppinen-Räisänen and Grönroos (2015). The authors show that, in the companies where they conducted their research, practitioners knew little about the most current and relevant concepts discussed in the academic environment; this finding differs from several other studies that have proven the efficiency of concepts for improving business performance in different sectors. Commonly, the interviewees reported knowing the concepts, yet they presented broad or incoherent definitions of what they meant and did not implement them in the way suggested by the best academic practices.

Possibly, the limited knowledge of some practitioners regarding theories, concepts and models can be explained by the belief shared by all respondents that, if they tried to follow an academic view, the complete marketing framework would be difficult to apply in practice. One of the reasons for this is in the structure of the marketing area in some companies; marketing is considered a "sales or communication appendix" - rather than being a more 
strategic area, and this restricts the ability to apply the discipline in its fullness. One of the practitioners (Analyst, consumer goods industry, 4 years of experience), for example, said that the marketing area of the company where he works does not supervise the price policy developed for its products, and this makes the theory of prices based on cost, competition and customer not applicable. However, he reflects that the price used by the company is based on its positioning, something that is within the scope of marketing.

It is worth considering, at this point, that marketing does not have to be a set of activities practiced only by the marketing area. The importance of the discipline for companies means that any are can (and should) adopt it, whenever this discipline interacts with the market. Thus, even if the marketing area only implements part of what would be considered marketing in the eyes of academicians, this does not mean that the company does not practice marketing fully. However, perhaps this understanding is difficult for some practitioners, because in many cases their knowledge about the marketing practices by their businesses is limited to the sole activity that their area is responsible for managing.

The difficulty in seeing marketing as strategic for companies is also discussed by Baker and Holt (2004). In their research, the authors show how practitioners could only describe marketing from a tactical perspective, associating the concept with communication activities, for example. While they can recognize the philosophy of "the consumer first" as being important, the idea of relating the strategic level of marketing to the tactical one, through which business objectives are achieved, seems to be a problem.

It is not surprising, therefore, that in such a scenario, practitioners find it difficult to exercise marketing the way it is presented to them in universities, since, as one academic alleges (private university professor with 3 years of experience), "from the moment you are embedded into a company, wanting to get things right, but having fears and insecurities, one will have to dance according to the music of that company".

Some practitioners, however, understand that they apply marketing theories, concepts and models in their practices, but in a different way from what the academic world believes to be the most correct. For them, this kind of application it would be a way to help "think about a subject more carefully", and not necessarily a principle that should be implemented rigidly. This is true to the point that they do not even consult academic literatures when they practice their marketing activities, claiming a "lack of time" - as also Mascarenhas et al. (2011) and Southgate (2006) indicate - or the need for "greater objectivity". One academic (public university professor with 14 years of experience) is aligned with this view when he states that "nowadays, people use and rely much more on intuition than on what they have learned in the academy". However, trusting only in intuition seems to be a mistake, from the point of view of academics, because failures can occur in companies, due to the lack of more theoretical foundation, as illustrated by an academician (private university professor, with 35 years of experience):

Some people say that in theory it is one thing and in practice it is another. I think the exact opposite! No one creates a theory; they arise when it is realized that $100 \%$ of the time a phenomenon occurs. These theories exist to make life easier for companies.

The perception that marketing can be practiced without greater academic reflections occurs due to the distancing that the discipline has from the management of companies. If marketing is not understood as essential for business strategy, it is then seen as less important (BROWNE; CUDDIHY, 2011). This becomes evident in one practitioner's report (Small Business Manager of the retail industry, with 11 years of experience), when he claims that it is difficult to convince management in his company to carry out reflection exercises in marketing and to show that the discipline is not merely a related or complementary activity to sales. It is difficult to make his superiors understand that, in fact, sales should be an important marketing component, but that marketing is not limited to sales. However, 
BBR

15,1

82

this perception is based on the view that marketing expenditures only bring results in the long run and, therefore, should not be prioritized. Concepts such as market positioning and segmentation will, then, be difficult to implement, because what his managers believe is that if the treatment at the point of sale is adequate, the customer will buy the product, even if it is the same or similar to the competitors' product.

This business behavior of relegating marketing to a less strategic status is explained by Klaus et al. (2014), when they argue that the discipline is no longer relevant for CEOs and managers of companies. Mostly, this reality is caused by a lack of alignment of the marketing area with the objectives of companies. According to the authors, misalignment occurs because marketing executives are overly preoccupied with tactical issues, rather than strategies; they are not able to relate marketing efforts to financial returns; they are obsessed with digital media and social networks; and they use irrelevant metrics to measure their actions.

In their day to day work, therefore, practitioners do not implement marketing from the perspective of an academic, that is, as a set of several elements; instead, they use parts of the marketing activity as a support for their practices, imagining that they are correct in their judgment, but not knowing whether the other elements that make up the company's marketing align with its vision. From the academic perspective, what these practitioners describe as marketing is not, in fact, what the discipline is supposed to be (HUNT, 2002; KAUPPINEN-RÄISÄNEN; GRÖNROOS, 2015). However, this does not seem to be a concern for practitioners, possibly because, even if the marketing results "do not go exactly as planned", companies do not seem to depend solely on marketing for their success.

\subsection{SUGGESTIONS FOR REDUCING THE DIVIDE}

Among some of the respondents, especially academics, there is a willingness to try to bridge the divide between academics and marketing practitioners. One justification for this is that, with a greater approximation between the academic and business sectors, the discipline can grow, both in theoretical and practical terms, and leave aside the "bad reputation that marketing is anything and that anyone can practice marketing", which smears the essence of the discipline (STOECKLA; LUEDICKE, 2015), as expressed by one academic (private university professor, with 5 years of experience):

Joint projects between academics and practitioners would be very interesting. The academy has the ability to look for solutions to market challenges and, for the academy, the presence of the market would be very welcome, because giving exposure and listening is good for the academy. In general, the exchange must be greater.

Based on this thought, academics and practitioners suggest actions that can be taken to try to bridge the divide between them: partnerships for the development of case studies, partnerships in projects that focus on solving real business problems, disciplines that have practical classes in companies, and workshops with the participation of academics and practitioners. Other researchers also indicate actions similar to those cited by the respondents as ways of bringing academic and business environments closer (BAKER; HOLT, 2004; KLAUS; EDVARDSSON, 2014; SOUTHGATE, 2006; STANTON, 2006).

The proposed actions revolve around the idea that business reality needs to be experienced more closely by academics, because this impacts in the teaching of marketing (HUGHES et al., 2011). Understanding that the discipline is intended to give students an introduction to business reality, especially when taught in undergraduate level, the respondents believe that such actions would make more sense for the students. The following account shows this thinking from the perspective of an academic (a public university professor, with 23 years of experience): 
The academy should seek to have more contact with companies to learn from the market, invite the company to teach the student. I see internships, but this is not the same thing. The student, when starting an internship, throws himself into the business life. It is not a transition. The professional does not go to the student to introduce him to the environment.

However, there is a need to establish specific purposes for such actions by academics and practitioners, be it to reinforce theories, concepts and models in marketing in practice, or to publicize the company, either for the purpose of future hiring, or for offering consulting in solving business problems.

It is possible that such actions may already be practiced by certain academics and practitioners. However, according to the respondents, they are not specific actions, since there is a need to increase the interaction, so that greater proximity is established between the parties. Instead of initiatives of individuals, whether of academics or practitioners, it must be something institutional, developed by universities and companies. A practitioner (Manager, entertainment industry, 30 years of experience), for example, comments on an experience which his company is going through with a university. Since he works in the entertainment industry, he was invited to participate in a creative economy program prepared by the academic institution. Through the program, seven students are trained within the company for a few months, learning marketing in practice. In the end, the students can be incorporated into the staff, through internship programs. According to the respondent, the program guarantees a holistic view of the company, such as in trainee programs, because the student learns about different areas before settling into one.

This type of interaction between academic and business circles is important in the respondents' view, especially because of the positive effect it would have on students; it serves as the transition from a purely academic life to a professional one, "without traumas", since the student learns to balance the demands of both environment. Thus, we avoid having students "give little value to the teaching of marketing, wanting to get rid of the academy... and not seeing the diploma as the only benefit left in the academy", as one academic (a private university professor, with 18 years of experience) puts it.

The benefits of diminishing the divide in marketing happen for both environments. Efforts to achieve such success should, therefore, come from academics and practitioners. For academics, the approach could bring them more subsidies to teach and research subjects aligned with market realities, shaping individuals better prepared for what they may face in their professional endeavors. For practitioners, in turn, the academic milieu could be, as one respondent indicates (Manager, Banking industry, 23 years of experience) a "major source of development of products, services, processes and knowledge to the market". There is room for mutual gains, in the view of the respondents, but there is still "a lot to do".

\subsection{MAIN FINDINGS OF THE RESEARCH IN THE LIGHT OF THEORY}

Interviews with academics and practitioners show how the divide between the academic and business environments in marketing occurs and how reversing it involves inherent difficulties. In order to clarify which are the most critical issues pointed out by the professionals interviewed, Table 2 summarizes the main findings of the study, comparing them with the findings of other studies related to the issue under discussion. 
BBR

15,1

84

Table 2. Key Research Findings

\begin{tabular}{|c|c|c|}
\hline Research Findings & $\begin{array}{l}\text { Author (s) that } \\
\text { corroborate the } \\
\text { findings }\end{array}$ & What the author(s) says \\
\hline $\begin{array}{l}\text { The academy is hermetic, } \\
\text { with its own language, } \\
\text { which makes it unappea- } \\
\text { ling for practitioners. }\end{array}$ & $\begin{array}{l}\text { Baker and Holt } \\
\text { (2004) } \\
\text { Edwards (2005) } \\
\text { Hughes et al. (2011) }\end{array}$ & $\begin{array}{l}\text { "Has the output from academic research resulted in } \\
\text { models and processes that are just too complex for } \\
\text { practitioners to adoptand adapt to their own situa- } \\
\text { tions?" (BAKER; HOLT, 2004, p.563). }\end{array}$ \\
\hline $\begin{array}{l}\text { Lack of further deepening } \\
\text { in marketing education, } \\
\text { although academics seek } \\
\text { to make their classes more } \\
\text { in line with business prac- } \\
\text { tices. }\end{array}$ & $\begin{array}{l}\text { Baker and Holt } \\
\quad(2004) \\
\text { Hunt }(2002) \\
\text { Stanton }(2006)\end{array}$ & $\begin{array}{l}\text { "Academic programs in marketing must adapt their } \\
\text { curriculum to more fully deal with technology and } \\
\text { information management issues. A course in data mi- } \\
\text { ning is one example of bridging the gap between the } \\
\text { theoretical domain of academicians with the knowled- } \\
\text { ge and skill set needs of practitioners" (STANTON, } \\
\text { 2006, p.241). }\end{array}$ \\
\hline
\end{tabular}

Few practitioners seek academic marketing knowledge; they do not have time and are not sure where to find it.
Almeida et al.

(2010)

Kauppinen-Räisä-

nen and Grönroos

(2015)

Southgate (2006)
"Scholarly knowledge was not shared across the firms participating in the present study" (KAUPPINEN-RÄISÄN; GRÖNROOS, 2015, p.363).

Academics teach marketing as a holistic activity; practitioners use marketing in a way different from that proposed by the discipline.

Almeida et al.

Baker and Holt (2004)

Hunt (2002) Southgate (2006)

Practitioners use their instincts more than theories, concepts and models in marketing.

Brennan and

Ankers (2004)

Lilien (2011)

Brennan (2004)

There is interest, especially among academics, in reducing the divide.
Hughes et al. (2011)

Klaus and Edvardsson (2014)
"Participants seldom start from a coherent, well-grounded conceptualization of the nature of the marketing discipline" (HUNT, 2002, p.305).
"Most traditional marketing decision making, while sometimes guided by the concepts from our literature, is largely based on managers' mental models, intuition, and experience" (LILIEN, 2011, p.197).

"As a community, we are often dissatisfied with the current processes allowing us to disseminate our knowledge... we as academic community should seek to provide both, guidance and solutions to practitioners" (KLAUS; EDVARDSSON, 2014, p.167-168).

\section{FINAL CONSIDERATIONS}

The present study sought to understand how academics and practitioners perceive the divide between the academic and business environments and how this affects the applicability of the main theories, concepts and models in marketing. For this purpose, interviews were conducted with 10 academics and 15 practitioners, and, after analyzing the data, it is possible to reach some final considerations.

Although there are authors (BRENNAN, 2004; BRENNAN; ANKERS, 2004) who defend the argument that it is not possible or beneficial to reduce the divide between academic and business circles, the data analysis showed that it was in the interest of both academics and practitioners to create ways to draw closer one another. These findings are aligned with other research that suggests ways for this to occur (KLAUS; EDVARDSSON, 2014; LILIEN, 2011). The reason behind such thinking is the gains in having each other as a partner. 
The road to such an approach still seems difficult, however. Much of this occurs because what is called "marketing" by practitioners seems to be only part of what would be the discipline in the view of academics. Practitioners do not, however, understand that their perspective is "incorrect". In fact, they believe that what they practice is marketing. Thus, the problem of the divide between the academic and business environments is not in the lack of will of a greater rapprochement between both parties, but in their understanding of what marketing is, in effect. Perhaps, because of this, the discipline will end up taking different configurations, without fixed rules on how it should be implemented, since there are different interpretations of what the practicing of marketing is. By this logic, there is not one type of marketing, but different "marketings". This would help explain why the discipline still carries a negative image (STOECKLA; LUEDICKE, 2015), since any practice is marketing and anyone practices marketing.

Such a disagreement between academic and business circles about marketing can be explained by the purposes that lead one or the other to practice the discipline. While academics have great concern in proving the rigor of their research, especially through complex and sophisticated methods that allow them to be considered scientific, practitioners are more interested in the relevance of the research for solving business problems. This is a reflection on how the area has developed historically. Although business schools initially had concerns about producing knowledge that was relevant to managerial practices, they were criticized, afterwards, for their lack of scientific rigor, and this changed the way they viewed the discipline in favor of a more methodological one (FARIA, 2007). Changing this perspective, therefore, requires balancing better relevance and rigor, including both in any proposal of what marketing is.

It is possible that the best balance will diminish what appears to be a certain bias of practitioners about applying theories, concepts and models in marketing, as advocated by the academy, and of academics about accepting business marketing practices without negative judgment. In fact, it may help both these professionals realize that practitioners need to find more time to read scientific studies and that academics can count on more business support to advance their research.

Even if the present study brings light to the issue discussed here, there are limitations on its scope. Because it is research undertaken only with scholars and practitioners in Rio de Janeiro, it may reflect some kind of particularity of the region. It is necessary, therefore, that other studies be carried out in other cities of Brazil, so that one can understand the dimension of the problem presented here.

Another limitation concerns the fact that the research encompasses the discussion both in the scope of undergraduate and postgraduate levels. Thus, it cannot be said whether the divide between academic and business circles is greater, less than, or equal to each of the two courses. Future studies could single out this phenomenon only at undergraduate or postgraduate level and analyze how much the distance is perceived as more or less present in these realities.

Other future developments for the present study could investigate the student's view of marketing on the subject, both undergraduate and postgraduate. As they are individuals who are still in the academic world, but many already working in companies, it is important to understand how the divide affects them. Possibly, this perspective would bring new information that would enrich the understanding of the phenomenon under study, especially with regard to the effects on those who are experiencing both contexts.

There could also be a future investigation into how much academics and practitioners would be open to teaching or practicing marketing from the perspective of the other. If the claim of practitioners who are interested in approaching the academy is true, it is necessary to investigate what type of relationship this professional would like and whether they would be willing to modify their way of acting to follow the practices of academics. On the other 
BBR

15,1

86

hand, if academics believe that companies do not practice marketing completely, it would be important to understand whether they would be willing to change their way of teaching, to encompass the business perspective in their classes.

It is hoped, therefore, that the present study has made some contribution so that the divide between the academic and the business environments can diminish. However, it is disturbing to imagine that this discussion is only read and reflected by other scholars. It is even more distressing to think that such discussions could advance in the area of marketing in Brazil, as it already occurs in the United States and Europe, and that efforts could be made to reach a greater approximation, only to discover that just a minority of practitioners were interested in the initiative simply because most did not "have the time" to read our articles. However, if the effort to reduce the divide first arises among academics, and then somehow reaches practitioners, lets make that be the way. Since academic hope is the last to die, let us be optimistic; maybe some practitioner will read this article and start the movement "beginning on the other side", allowing us to see, in the near future, greater relevance and rigor, together, in marketing research.

\section{REFERENCES}

ARGYRIS, C.; SCHON, D.Theory in practice: increasing professional effectiveness, San Francisco: Josey Bass, 1974.

ASTLEY, W.G.; ZAMMUTO,R.F. Organizational science, managerial practice, and language games. Organization Science, v.3, n.4, p.443-460, 1992.

BAINES, P.; BRENNAN, R.; GILL, M.; MORTIMORE, R. Examining the academic/commercial divide in marketing research. European Journal of Marketing, v.43, n.11/12, p.1289-1299, 2009.

BAKER, M.J. Who we are and what we do.Journal of Marketing Management, v.16, n.7, p.679-696, 2000.

BAKER, S.; HOLT, S. Marketing marketers accountable: a failure of marketing education? Marketing Intelligence \& Planning, v.22, n.5, p.557-567, 2004.

BARTELS, R.The history of marketing thought.2ed. Columbus: Grid, 1976.

BOURASSA, M.; CUNNINGHAM, P.; HANDELMAN, J. How Philip Kotler has helped to shape the field of marketing. European Business Review, v.19, n.2, p.174-192, 2007.

BRENNAN, R. Should we worry about an "academic-practitioner divide" in marketing? Marketing Intelligence \& Planning, v.22, n.5, p. 492-500, 2004.

BRENNAN, R.; ANKERS, P. In search of relevance - Is there an academic-practitioner divide in business-tobusiness marketing? Marketing Intelligence\& Planning, v.22, n.5, p. 511-519, 2004.

BRUYNE, P.Dinâmica das pesquisas em ciências sociais.Rio de Janeiro: Francisco Alves, 1991.

BROWNE, S.; CUDDIHY, L. Questioning the currency of marketing planning today.Irish Marketing Review, v.21, n.1-2, p.49-57, 2011.

DELOITTE.Mind the gaps, The 2015 Millennials Survey, 2015. Disponível em: <www2.deloitte.com/ global/en/pages/about-deloitte/articles/millennialsurvey.html >.Acesso em: 20 de abril de 2016.

DUARTE, R. Entrevistas em pesquisa qualitativas. Curitiba: Educar em Revista, 2004.

EDWARDS,M. Organizational identification: a conceptual and operational review, International Journal of Management Reviews, v.7, n.4, p.207-230, 2005.

EMPSON, L. My affair with the "other": identity journeys across the research-practice divide. Journal of Management Inquiry, v.22, n.2, 229-248.

FARIA, A. Relevância ou rigor? GV Executivo, v.6, n.3, p.39-43, 2007.

HE, H., MUKHERJEE, A., I am, ergo I shop: does store image congruity explain shopping behaviour of chinese consumers?Journalof Marketing Management, v.23, n.5-6, p.443-460, 2007.

HEGENBERG, L.Etapas da Investigação Científica, São Paulo: EPU-EDUSP, 1976.

HUGHES, T.; BENCE, D.; GRISONI, L.; O'REGAN, N.; WORNHAM, D. Scholarship that matters: academic-practitioner engagement in business management. Academy of Management Learning \& Education, v.10, n.2, p.40-57, 2011.

HUNT, S. Marketing as a profession: on closing stakeholder gaps. European Journal of Marketing, v.36, n.3, p.305-312, 2002.

HUNT, S. Controversy in Marketing Theory: for reason, realism, truth, and objectivity. New York and London: M.E. Sharpe, 2003.

KAUPPINEN-RÄISÄNEN, H.; GRÖNROSS, C. Are service marketing models really used in modern practice? Journalof Services Management, v.26, n.3, p.346-371, 2015. 
KERLINGER, F.Metodologia da pesquisa em ciências sociais. São Paulo: EPU-EDUSP, 1980.

KLAUS, P.; EDVARDSSON, B.The road back to relevance - how to put marketing (and marketing scholars) back on the Top Managements' agenda.Journal of Services Management, v.25, n.3, p.166-170, 2014.

KLAUS, P.; EDVARDSSON, B.; KEININGHAM, T.; GRUBER, T. Getting in with the "In" crowd: how to put marketing back on the CEO's agenda. Journal of Service Management, v.25, n.2, p., 195-212, 2014.

LEE, N.; GREENLEY, G.E, The theory-practice divide: thoughts from the Editors and Senior Advisory Board of EJM. European Journal of Marketing, v.44, n.1-2, p.5-20, 2010.

LILIEN, G. Bridging the academic-practitioner divide in marketing decision models. Journalof Marketing, v.75, n.4, p.196-210, 2011.

MASCARENHAS, A.; ZAMBALDI, F.; MORAES, E. Rigor, relevância e desafios da academia em administração: tensões entre pesquisa e formação profissional. RAE - Revista de Administração de Empresas, v.51, n.3, p.265-279, 2011.

PACHECO, R.; RODRIGUES, T.; SOUSA, R. Marketing: gestão e conhecimento científico.Revista de Negócios, v.18, n.1, p.53-62, 2013.

PFEFFER, J., FONG, C.T., The end of business schools? Less success than meets the eye.Academy Management Learning \&Education, v.1, n.1, p.78-95, 2002.

SAMPAIO, C.; PERIN, M.; LUCE, F.; SANTOS, M.; SANTINI, F.; OLIVEIRA, M.; LENZ, G. Pesquisa Científica da área de marketing no Brasil: uma revisão da primeira década do século 21 . RAC - Revista de Administração Contemporânea, v.16, n.3, p.459-478, 2012.

ROBERTS, J.; KAYANDE, U.; STREMERSCH, S. From academic research to marketing practice: exploring the marketing science value chain. International Journal of Research in Marketing, v.31, n.2, p.127140, 2014.

ROWLEY, J. Evidence-based marketing: a perspective on the 'practice-theory divide'. International Journal of Market Research, v.54, n.4, p.521-541, 2012.

SHETH, J.; GARDNER, D.; GARRET, D. Marketing theory: evolution and evaluation. New York: John Wiley \& Sons, 1988.

SOUTHGATE, N. The academic-practitioner divide: finding time to make a difference. Marketing Intelligence \& Planning, v.24, n.6, p.547-551, 2006.

STANTON, A. Bridging the academic/practitioner divide in marketing: An undergraduate course in data mining. Marketing Intelligence \& Planning, v.24, n.3, p.233-244, 2006.

STOECKLA, V.; LUEDICKE, M. Doing well while doing good? An integrative review of marketing criticism and response.Journal of Business Research, v.68, n.12, p.2452-2463, 2015. 